\title{
Accounting
}

\section{The macroeconomic determinants of stock price fluctuations in Amman Stock Exchange}

\author{
Abdallah Ghazo ${ }^{a^{*}}$, Ziad Abu-Lila ${ }^{a}$ and Sameh Ajlouni ${ }^{b}$
}

${ }^{a}$ Faculty of Economics and Administrative Sciences, Department of Economics of Finance and Business, P.O.BOX 130040- 25113, Mafraq, Jordan ${ }^{b}$ Faculty of Economics and Business Administration, Department of Economics, Yarmouk University, P.O.Box 566 -21163, Irbid, Jordan

\section{H R O N I C L E}

Article history:

Received: July 2, 2020

Received in revised format:

September 302020

Accepted: October 15, 2020

Available online:

October 15, 2020

Keywords:

Macroeconomic determinants

Fluctuations of stock prices

Amman Stock Exchange

GARCH model

\section{A B S T R A C T}

The purpose of this study is to identify the key macroeconomic variables that affected stock price fluctuations in Amman Stock Exchange during the period 1980-2018. Using Augmented Dickeyfuller (ADF) test, it was found that the variables did not have the same degree of integration. According to Breusch-Pagan-Godfrey test, the residuals violated the constant variance assumption under Ordinary Least Square (OLS) model. Therefore, the study employed Generalized Autoregressive Conditional Heteroskedasticity $(\mathrm{GARCH})$ methodology to analyze the model after taking the first difference of natural logarithm for all variables to be stationary at the same level and to show the fluctuation in the variables. It was found that fluctuations in portfolio investment and in industrial production index are statically significant to lead fluctuations in the stock price index in Amman Stock Exchange and they follow the same direction, whereas fluctuations in real effective exchange rate, real interest rate, and Brent crude oil prices were statically significant to lead fluctuations in the stock price index but in the opposite direction.

\section{Introduction}

The relationship between macroeconomic variables and the stock market variables has attracted the attention of many researchers. The reason for this attention is the definite correlation between the changes that happen to macroeconomic variables and the fluctuations in the financial indicators of the stock market. This has been confirmed by the results of many empirical studies, such as Nisha (2016) and Şükrüoğlu and Nalin (2014). Cumulative Capital formation is considered a prerequisite for achieving targeted economic growth and economic development. Since the stock market is regarded as the right place for collecting and allocating funds for investment, countries necessarily have to establish this market which is one of the components of the financial system. Therefore, the stock market mobilizes savings in order to fund economic projects and, thus, creates new opportunities for investors. Furthermore, it recycles fiscal surpluses and provides liquidity to those involved in the market. In many countries, establishing stock markets is associated with the spread of corporations which have multiplied and had various sizes and many areas of activities. This enriched the variety of financial instruments raised for deliberation in the different stock markets. As a result, more dealers would be attracted as there are more opportunities available for holders of fiscal surpluses who need a suitable option for investing their money.

* Corresponding author.

E-mail address: aghazo@aabu.edu.jo (A. Ghazo) 
What has helped improving the stock market are the wide spread of multinational corporations and the technological revolution in transport and communication which has led many countries to connect their markets with the international stock markets in order to increase integration and convergence among them. Therefore, capital flows taking the form of foreign investment increased in those markets. Thus, the stock markets of some countries have witnessed a great improvement and a high prevalence. In addition, they managed to mobilize savings and, effectively, direct them to different investments. This has helped accelerating economic growth in these countries, especially in the shadows of globalization, financial liberalization and economic openness. Furthermore, these markets have become increasingly important since their activity is considered an indicator of the strength of economy, whereas low market activity and poor liquidity are both indicators of the weakness of economy. The stock market is regarded as an integral tool for measuring economic performance. Studies have shown that the stability and the development of stock markets are important for economic growth in both developing and developed countries (Tachiwou, 2009). Therefore, there are many countries, especially the developing ones, which have chosen to improve the work of their stock markets in order to keep in pace with international standards and to facilitate the process of integration into the world markets through adopting the mode of open markets as a mechanism for achieving a scale of investments that helps improving their economic performance. Nevertheless, the stock market is known for its sensitivity to macroeconomic conditions. Therefore, it is expected that the macroeconomic variables such as gross domestic product, interest rates, inflation rates, exchange rate, money supply and external debt would affect the fluctuations in stock prices, and then strengthen or weaken the confidence of both domestic and foreign investors in these markets (Azeez \& Obalade, 2018; Zhou et al., 2015).

Economic theory expects that there is a connection between the real macroeconomic activities and the level of stock prices in the stock market. The changes in macroeconomic variables cause fluctuations or instability that might cause crisis in the stock prices. Therefore, it can be said that stock markets are not independent from macroeconomic conditions, whether local or global. As a result of the critical changes in the macroeconomic variables that Jordan went through during past periods in addition to the stock price fluctuations, this study intends to investigate the compatibility of these expectations in the Jordanian economy during the period 1980-2018. This study aims at identifying the most prominent macroeconomic determinants, such as the interest rate, the real effective exchange rate, and the level of industrial production, the average price of the world oil, the foreign portfolio investment flows and the foreign direct investments flows to the Jordanian economy, all of which can affect the stock price fluctuations in Amman Stock Exchange. Thus, it would be possible to predict the direction of these fluctuations in the future. In order to achieve the desired objectives of this study, the following statement has been tested:

The macroeconomic variables (the interest rate, the real effective exchange rate, the industrial production index, the average price of the world oil, the foreign portfolio investment flows and the foreign direct investments flows) are not considered as determinants which affect the stock price fluctuations in Amman Stock Exchange.

Investors carefully keep an eye onto the changes that occur in the stock market in order to make their decisions and take precautions in case there is no expected stability in that market, especially as these expectations might be, directly or indirectly, affected by the macroeconomic variables prevailing at the time. Therefore, this study is important to help investors make the right decisions regarding the expected economic changes that are reflected on the performance of the stock market. It is also important for those who are responsible for the economic policies in order to help them take the necessary action to control the alleviation of the expected fluctuations of stock prices by controlling the macroeconomic variables. Consequently, the stock market becomes more stable, safe and attractive to investors, and it achieves the goal it was established for. This study faced some limitations, the most important of which was the lack of data on the net portfolio investments during the entire study period. The available data starts from 1996. Before this year, the net portfolio investment was included in the financial account in the Jordanian balance of payments without a special item. Thus, in this study, it was replaced by the financial account after excluding the foreign direct investments from it ${ }^{1}$. Another challenge faced by this study is the lack of data on the stock price index weighted by the free stock before 1999. Therefore, the study used a stock price index weighted by the market value of capital.

\section{Literature Review}

A considerable volume of theoretical and empirical research has documented evidence on the existence of a relationship between the real macroeconomic activities and the stock market indices. This relationship was a result of the transition of the effects of domestic and foreign macroeconomic activities to the different stock market indices, especially in countries with advanced economies. The results of the applied studies indicated that the transmission of the impact of macroeconomic indicators fluctuations to stock prices takes place through future cash flows and expected discount rates, which affect the real value of stock returns, and then cause the decrease in demand and trading volume in the financial market. Thus, the stock price index retreats (Chen et al., 1986; Geske \& Roll, 1983; Fama, 1981).

1 -The analysis was conducted twice, the first time using the portfolio investments for the period available and the second using the financial account (shown later in the part which deals with the standard analysis). 
There are many previous studies which used a number of macroeconomic indicators to represent the risks that stock markets face, especially emerging markets. Some of these studies were based on theories of asset pricing (Ross, 1976) that depends on some macroeconomic factors, such as the quantity of industrial production, inflation rates, interest rates and global oil prices (Hamao, 1987; Huang \& Kracaw, 1984). These factors affect the expected stock returns over time. This leads to a change in demand on them, and changes their prices. This is the logic of the methodologies employed by the previous studies to understand the relationship between the expected revenue and these factors. The assumption proposed is that this relationship takes a unidirectional from macroeconomic variables to the stock returns. Despite the importance of the dynamic links between the macroeconomic variables and the stock market indicators, they have not been widely explored until recently and only for developed markets. Moreover, developing markets have been neglected, especially in countries with less economic growth. The reason for this is mainly the high intervention of these governments in economic activity. In addition, they have not established stock markets until recently, and there has been no accurate or timely information about the private companies (Bekaert et al., 1998). Therefore, developing stock markets are likely to be affected by economic policies. This way, stock markets indicators can be predicted based on macroeconomic indicators. Regarding the mechanism of affecting the volatility of stock prices by fluctuations in macroeconomic variables, we mention how exchange rate may affect stock prices through the terms of trade. The depreciation of the local currency increases the volume of export provided that the demand for export commodities is elastic. This results in increasing cash flow to local companies. It also results in increasing the demand for their shares whose prices would be increased, too (Geske \& Roll, 1983). Regarding the relationship between the interest rate and stock prices, the previous studies have shown that this relationship is negative. The high interest rate increases the cost of borrowing for equity investment. This causes the low demand and the low prices of it. In addition, there would be a chance that the risk-free high interest rate might be preferred by investors over risky stock investment (Geske \& Roll, 1983; Fama \& Schwert, 1977). Furthermore, the high inflation rate would result in increasing risk-free nominal interest rates on the shares that the investor accepts. As a result, this increases the discount rate used in stock valuation, which would lead investors to be reluctant to invest in equity portfolios whose prices would be decreased. Unless the cash inflows are increased to the same extent the inflation rate is, the effect of discount rate will be neutral (Chen, 2009). Regarding the level of the real economic activity which is often measured by the index of the industrial production quantities, it is expected that it will have a positive impact on the future cash flows and, thus, on stock prices in the same direction (Fama, 1981). Over time, the dynamic relationship between the macroeconomic variables and the stock market indicators has been strengthened as a result of the rapid developments in the volume of international trade, especially in investment portfolios. Other factors that enriched this relationship are foreign direct investment and the liberalization of most countries' economies, especially in the last two decades, in order for these countries to integrate their economy into the world economy to lower the cost of capital and increase demand for stock investments which might lead to the increase of its prices as well as its benefits. Empirical studies have shown this, especially when the process of economic integration in a country is largely associated with its macroeconomic policies and the global macroeconomic policies. That is when the relationship between macroeconomic variables and stock prices becomes fundamental to understand the best thing that may happen in the developing stock markets (Muradoglu et al., 2000).

One of the empirical studies which dealt with the effect of the macroeconomic indicators on the stock market indicators is the study of Al-Refae (1999). The study aimed at analyzing the relationship between the macroeconomic variables and the performance of the Jordanian capital market. The results showed that the macroeconomic variables of money supply, the interest rate, inflation, the exchange rate, the gross domestic product and remittances of workers affect all of the indicators of the Jordanian capital market that have to do with stock prices, the trading volume and the number of traded shares. Moreover, the most sectors affected by these variables are the industrial sector regarding its stock prices, the services sector regarding its volume of trade and the banking sector regarding its number of shares. The study of Nasseh and Strauss (2000) addressed the issues of stock prices and the local and international macroeconomic activity: the approach of co-integration. The study aimed at investigating the long run relationship between stock prices on the one hand and the local and international macroeconomic activity on the other hand in six European economies. The Johansen Co-integration Test used in this study showed that the levels of stock prices are largely associated with industrial production, long and short run interest rates and foreign equity prices. Furthermore, after analyzing variance components, the results showed the explanatory power of the macroeconomic variables used in predicting the disparate level of stock prices. Therefore, the future stock prices can be predictable according to the prevalent macroeconomic activity. Another study by Ratanapakorn and Sharma (2007) investigated the long and short term relationship between the American stock market indicator and six macroeconomic variables during the period from the first quarter of the year 1975 to the last quarter of the year 1999. The results showed that there is a negative correlation between stock prices and the interest rate in the long run as well as a positive correlation among each of the money supply, the industrial production, inflation, the exchange rate and the interest rate in the short run. Moreover, applying Granger Causality Test, it was shown that every macroeconomic variable does not cause a change in stock prices in the short run. Al-Hamouri's study (1999) examined the relationship between the fluctuations in stock prices and the fluctuations in the macroeconomic variables. The study investigated the existence of a causal relationship between stock prices on the one hand and the money supply, the interest rate, the index of industrial production and the inflation rate on the other hand. The countries involved in the study were Jordan, Turkey, Tunisia, Kuwait and Egypt. Using GARCH model, the results of study showed that the fluctuation in 
stock prices does not clearly affect the macroeconomic variables. In addition to this, the fluctuation in the macroeconomic variables is not effectively reflected in the Arabic stock markets under study.

El-Nader and Alraimony (2013) used monthly data over the period 1990-2011. Depending on the co-integration approach and by analyzing variance components, it was shown that all of the macroeconomic variables: the percentage of the money supply of the gross domestic product, the percentage of the traded value of shares of the gross domestic product, the percentage of private credit of the gross domestic product and the consumer price index have a positive effect on the capital market development. However, the remittances of workers abroad have a negative effect on the development of the Jordanian capital market. The study of Nisha (2016) aimed at investigating the effect of the local and international macroeconomic determinants on the equity returns of Dhaka Stock Exchange in Bangladesh. Applying VAR model, the study showed that there is an effect that has a statistical significance of the money supply on the equity returns. On the other hand, it showed that the global price index has no statistically significant effect on the equity returns of Dhaka Stock Exchange. This indicates that the links between Dhaka Stock Exchange and the world stock markets are weak. Moreover, Demir's study (2019) aimed at analyzing the effects of some macroeconomic factors on the Turkish capital market index (Istanbul Stock Exchange) during the period 2003-2007. Applying ARDL approach, the study showed some remarkable results. One of these results is that economic growth, the value of the local currency, portfolio investments and foreign direct investments raise the stock price index, whereas the interest rate and the world price of oil negatively affect the value of the stock price index in Istanbul Stock Exchange. Finally, Anichebe's study (2019) addressed the issue of the macroeconomic determinants that might affect stock prices in Nigeria. Using time series data of the period 1981-2017, results showed that the macroeconomic variables have a long run relationship with the stock prices in Nigeria. In particular, treasury bills have a negative effect on stock prices, whereas each of the exchange rate, gross national income and inflation has a positive effect on stock prices in the long run.

\section{Development of general Stock Price Index in Amman Stock Exchange}

With the increasing number of public shareholding companies and as a result of trading their shares in unregulated markets, the government needed to seriously consider establishing a legal market which organizes the issuance of securities and dealing with them. In addition, it guarantees the safety, the accessibility and the prompt handling of these securities. Moreover, it protects small savers by finding a new mechanism for determining the fair price of securities depending on the forces of supply and demand. The successive economic development plans called for establishing this type of markets. Therefore, a stock market was established in 1976 as a public institution with a legal personality and financial and administrative autonomy, which was regarded as a significant step on the path of developing the financial sector in Jordan. Furthermore, this market had two main roles. The first one is the role of the regulatory authority of securities, also known as Securities and Commission Exchange, whereas the other is the role of the traditional stock exchange. As a result, the Jordanian stock market has become one of the promising markets in the region for foreign investors, with an increase in the inflows of portfolio investments and foreign direct investments to the Jordanian economy. Since 1999, Amman stock exchange has taken office as a non-profit civil society institution with financial and administrative independence. It is also considered a single authorized point to conduct business as a formal market for trading securities in Jordan. Moreover, it is controlled by the Securities Commission, based on the provisions of the Securities Act No.23 of 1997. Then, the New Securities Act No. 76 of 2002 was passed to allow establishing more markets for trading securities in Jordan. In February 20, 2017 Amman Stock Exchange was registered as a civil society institution which is wholly owned by the government. Furthermore, Amman Stock Exchange Company is considered the realistic and legal successor to Amman Stock Exchange. Moreover, Amman Stock Exchange Market has gone a long way since it was established. The trading volume of the market increased from 9.7 million JD in 1978 to 2.32 billion JD in 2018 . In addition to this, the market value of the shares subscribed in 2018 exceeded about 16.2 billion JD compared with approximately 286 million JD at the end of 1978. Furthermore, the number of listed companies increased from 66 companies in 1978 to 195 companies in 2018. According to Fig. 1 that explains the direction of the general stock price index in Amman Stock Exchange (SPI) over the period 1980-2018, it is clear that there is a significant variation in the values of this index. Its arithmetic average reached 2070 points, and its coefficient of variation reached 0.75 . This is an indication of the increase in fluctuations which reflect the risk of investing in the shares of this market. In addition, turning to figure (1), it is found that the overall direction of the price index started to increase since the beginning of the period until approximately the year 2005 despite of the significant changes that occurred in some years. In 1984, the overall direction of the price index decreased because of the consequences of the Iran-Iraq War and the events in Lebanon. In 1991, it also decreased as a result of the Gulf War and the accompanying consequences on Jordan due to its position on this war. After that period, there was an increase in the index value as the Jordanian government adopted the economic adjustment program. In addition, the investments of Jordanians, especially those returning from abroad due to the Gulf War, increased. However, during the time 1990-2003, a fluctuation occurred as a result of some events such as the change in the interest rate in Jordan, setting up a web site for Amman Stock Exchange, the accession by Amman Stock Exchange to the Federation of Exchanges and to the Arabic Securities Exchange Commissions and, finally, the occupation of Iraq in 2003 and the accompanying break down of security which affected the Jordanian foreign trade with Iraq that was a strategic partner to Jordan. Subsequently, the index increased until it reached a 
peak in 2005 as result of the legislative, structural and technical developments of the Jordanian stock market as well as the positive performance of the macroeconomic variables in Jordan regarding economic growth rates and the positive expectations of the economic performance amid decreasing interest rates. In addition, the increase in the graph is also due to the continued flow of Arabic investments, especially by Iraqis who entered Jordan with their money with the backdrop of the war there. This was referred to by the annual report of Amman Stock Exchange in 2005.

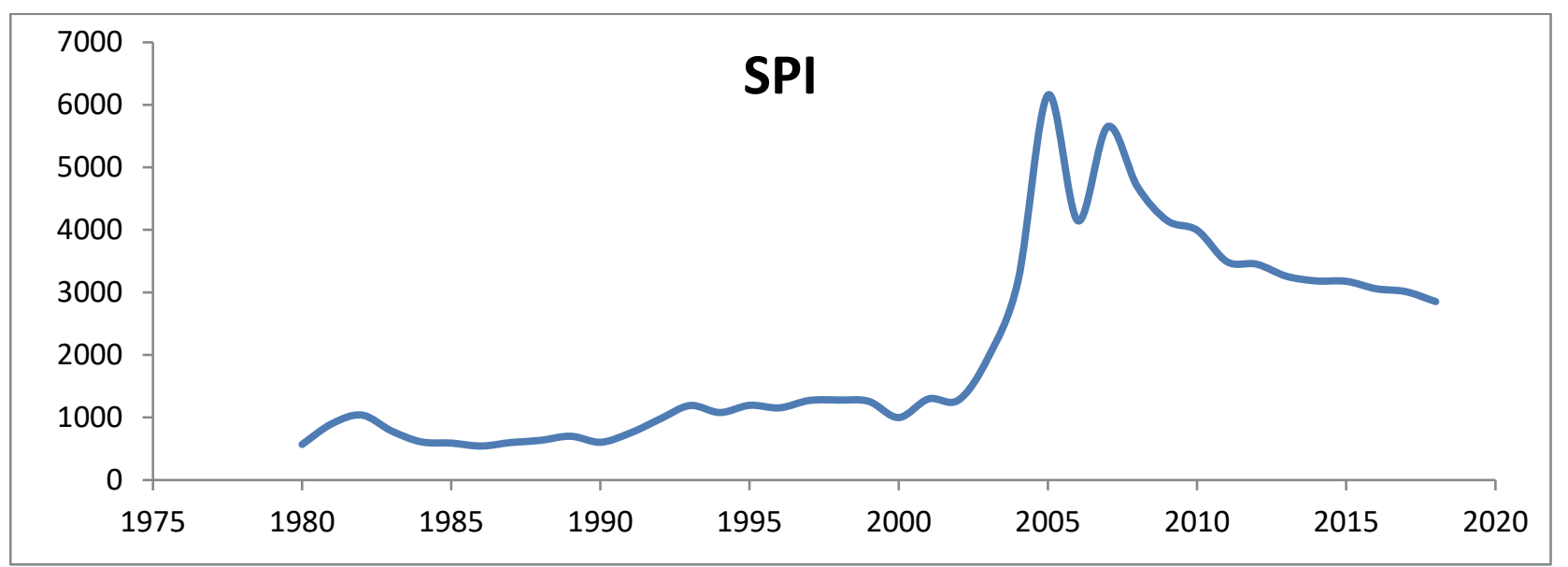

Fig. 1. The Development of the General Stock Price Index (SPI) in Amman Stock Exchange

In 2006, as it was expected, the price index clearly decreased as a result of the clear rise in world oil prices and liberalizing the prices of oil derivatives in Jordan. This negatively affected the volumes of local production due to the high cost. Moreover, the decrease was caused by the sharp decline in most of the stock markets in the region. However, the price index recovered in 2007 as Amman Stock Exchange became a full member of the World Federation of Exchanges. In addition, the role played by His Majesty the King in the groundbreaking for the Jordanian National Financial Status building was significant as he wanted it to be a regional financial center in the Arab region. This was the last increase of the price index as it subsequently decreased until the end of the study period as a result of the global financial crisis and the accompanying low level of the Jordanian economy. Consequently, this affected the trading volume. In addition, the effect was caused by the Arab Spring consequences and the accompanying difficult economic situation that overshadowed all sectors which remained to this day. All in all, through this quick review of the behavior of the stock price index during the study period, it is obvious that this index was generally affected by the macroeconomic variables, whether local or global. This is a natural consequence of an economy characterized by its small size in comparison with the other economies as well as its high degree of openness to those economies. However, the next part of the study deals with the analytical aspect whose findings highlight the effect of the local and global macroeconomic variables on the stock prices index.

\section{Methodology}

An appropriate quantitative methods and statistical tests are considered as a proper way to reach reliable results in the testing process for measurement, analysis and prediction. Thus, this study is based on the standard analytical method and applies a standard model which was used in previous studies (Demir, 2019) along with some modifications which are consistent with the Jordanian economy. Accordingly, the format of the model is as follows:

$$
S P I_{t}=\beta_{0}+\beta_{1} R R_{t}+\beta_{2} I N I_{t}+\beta_{3} F I D_{t}+\beta_{4} R E X_{t}+\beta_{5} C R P_{t}+\beta_{6} D U M_{t}+\varepsilon_{t},
$$

In which SPI stands for the stock price index weighted by the market value of capital. It is considered one of the most significant indices of Amman Stock Exchange. In addition, it is used in order to reflect stock price movements in the stock market. This helps the investor make his decision, regarding buying or selling. Furthermore, one of the characteristics of this number is that it depends on the method of weighing the market value of the sample, in which it gives every company weight that equals what its market value consists of as a part of the market value of the sample as a whole. In this study, this number was used as its data were provided during the entire study period unlike the general index weighted by the free stock whose data were provided only since 1990 onward. Thus, this period is not enough for achieving credible results, especially as the model consists of many independent variables. This needs a larger number of degrees of freedom.

RR: the real interest rate. The study used the re-discount rate minus the inflation rate. The re-discount rate was used since it represents the price paid by the Central Bank for the deposits of the commercial banks, whether it is an investment for one 
night, one month or more. Moreover, this price is considered an index of interest rates for the commercial banks whose interest rates are not less than this price ${ }^{(2)}$.

INI: industrial production quantity index, which is used to refer to the level of the real economic activity.

FID: portfolio investment (Liabilities), also known as foreign indirect investment, which covers non-residents ownership of domestic equity, debt securities and financial instruments, other than those included in foreign direct investment and reserve assets.

REX: the index of real effect exchange rate, which is used to assess the currency's strength in relation to the basket of other major currencies. It also reflects the real value of the local currency in the local and foreign markets alike.

CRP: the average price of Brent crude oil. This variable was used since the capital market fluctuations are not independent from the fluctuations in the outside world, especially for an energy importing country whose economy is affected by the fluctuations of world energy prices. Therefore, this index was used as one of the determinants of the stock price fluctuations in the local capital market.

DUM: a dummy variable used for capturing the impact of economic or political instability that Jordan had passed through, which would affect stock prices in the capital market. Examples of this would be the fall in the Jordanian dinar exchange rate in 1989, the first Gulf War in 1991, the occupation of Iraq in 2003, the global financial crisis in 2008 and the Arab Spring in 2011.

$\varepsilon_{t}$ : the random error which is supposed to be normally distributed with zero mean value and a constant variance.

$\beta_{0}, \ldots, \beta_{6}$ : The parameters of the model which will be estimated after following the econometrics methodology which is illustrated in the flowchart below.

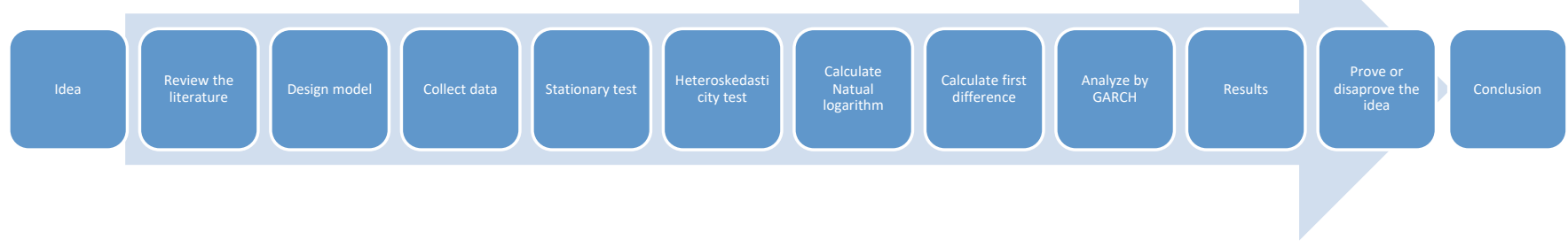

\section{Empirical Results}

Fig. 2. Flowchart of the research methodology.

To avoid misleading results, the study did some procedures. First, it tested the stationary of the data of the variables of the model in order to choose the appropriate analysis methodology because most time-series data, especially financial data, tend to increase or decrease over time. This causes the non-stationary of the arithmetic mean and the variance of series values over time (Gujarati, 2009). Thus, using (OLS) method will not be feasible, and it will give misleading results if it is applied to nonstationary data. However, to ascertain data stationary, this study relied on the Augmented Dickey Fuller test (ADF) to determine the need for additional analyses in order to choose the appropriate methodology for analyzing the model (Phillips \& Hansen, 1990).

Table 1

Augmented Dickey-Fuller (ADF), Unit Root Test

\begin{tabular}{|c|c|c|c|c|c|}
\hline Variable & t-value & Critical value & Sig. & Lags & Stationary \\
\hline SPI & -7.9 & -2.63 & $1 \%$ & 0 & First difference* \\
\hline RR & -6.91 & -2.63 & $1 \%$ & 0 & First difference* \\
\hline INI & -5.23 & -2.63 & $1 \%$ & 0 & level* \\
\hline FID & -6.32 & -4.23 & $1 \%$ & 0 & level** \\
\hline REX & -3.39 & -2.63 & $1 \%$ & 0 & First difference* \\
\hline CRP & -6.23 & -2.63 & $1 \%$ & 0 & level* \\
\hline
\end{tabular}

*: without trend and intercept, $* *$ with trend and intercept.

After testing data stationary, the results shown in Table 1 demonstrates that some variables are stationary at the level, and some are stationary at the first difference. Therefore, the analysis cannot be conducted using (OLS) method unless we take the first difference of all the time series. Since the model contains financial data that change frequently, this might lead to the unequal

2- The analysis was conducted using the borrowing rate which represents the cost of the funds required for equity investment in addition to using the deposit rate which reflects the opportunity cost of equity investment after someone waives their money that they lend for a limited time. However, statistically significant results were not accepted since the investment in the stock market could not totally rely on borrowed funds, nor could it rely on private funds. Thus, it was appropriate to use the rediscount rate to reflect the prevailing rate of interest in Jordan in general. 
variance of the error term in the analysis. Therefore, it was necessary to test the problem of heteroskedasticity to make sure that the variance of the error term is constant. According to the results of Breusch-Pagan-Godfrey test and (ARCH) Test shown in Table 2, it's clear that there is a problem of heteroskedasticity based on the probability value of both (F) and (Chi) tests which found to be less than $5 \%$.

Table 2

Heteroskedasticity Test.

\begin{tabular}{cc}
\hline & Heteroskedasticity Test - ARCH \\
\hline F-statistics $=10.35$ & Prob. $=0.0028$ \\
Obs*R-squared $=8.44$ & Prob. Chi- squared $=0.0037$ \\
& Heteroskedasticity Test - Breusch- Pagan - Gogfry \\
F-statistics $=11.35$ & Prob. $=0.0018$ \\
Obs*R-squared $=15.35$ & Prob. Chi- squared $=0.016$ \\
\hline
\end{tabular}

To overcome the heteroskedasticity problem, there was a need for another appropriate methodology to estimate the model, especially as the subject of the study is mainly concerned with fluctuations. These fluctuations cannot be measured by the unconditional variance since the unconditional variance of the time series is a unique number that does not take into account the changes that occurred in the past. Therefore, the study can rely on (Gujarati, 2009).

---Autoregressive conditional heteroscedasticity $(\mathrm{ARCH}(\mathrm{p}))$, which handles modeling the variance by calculating the variance of the error term. Then, conditional estimates of that variance are made. These estimates are made simultaneously for the mean equation

$$
Y_{t}=\beta_{0}+\sum_{i=1}^{n} \beta_{i} X_{t i}+e_{t}
$$

where $(\mathrm{X})$ is the matrix of the independent variables, and $e_{i}$ is the random error which is distributed in zero mean and nonconstant variance $\left(\sigma_{\mathrm{t}}^{2}\right)$, and the variance formula equation which depends on the lags of the past error thresholds until the previous period $(\mathrm{t}-1)$ as follows:

$\sigma_{t}^{2}=\alpha_{0}+\sum_{i=1}^{p} \alpha_{i} e_{t-1}^{2}$

--- Or generalized autoregressive conditional heteroskedasticity model $(\operatorname{GARCH}(\mathrm{p}, \mathrm{q}))$, which makes a simultaneous estimation of the mean equation in addition to the variance equation which depends on the lags of the past error thresholds until the previous period $(\mathrm{t}-1)$ and the past thresholds of variance lags until the previous period $(\mathrm{t}-1)$ as:

$$
\sigma_{t}^{2}=\alpha_{0}+\sum_{i=1}^{p} \alpha_{i} e_{t-1}^{2}+\sum_{i=1}^{q} \delta_{i} \sigma_{t-1}^{2}
$$

This means that the difference between (ARCH) $(p)$ and $(\mathrm{GARCH})(\mathrm{p}, \mathrm{q})$ is the variance equation to which the thresholds of conditional variance lags are added in $(\mathrm{GARCH})(\mathrm{p}, \mathrm{q})$ model. After conducting the analysis and making sure of the significance of the parameters of the variance equation in GARCH $(p, q)$ model, it was confirmed to be valid in estimating the study model, especially after it has become superior to $(\mathrm{ARCH})(\mathrm{p})$ model and more prevalent in scientific studies. Since the current stock prices are affected by the level of the expected risks, Engle and Robins suggested, in 1987, ARCH - M model which allows inserting variance or standard deviation into the remainders of estimation as an independent variable in the mean equation. Moreover, since $(\mathrm{GARCH})$ model is more popular than $(\mathrm{ARCH})$ model, the standard deviation was inserted into $(\mathrm{GARCH})$ model. Thus, the results of estimating the equations of both mean and variance are shown in the following table (3):

\section{Table 3}

\begin{tabular}{|c|c|c|c|}
\hline \multicolumn{4}{|c|}{ Mean equation } \\
\hline Variable & coefficient & Z-statistics & Level of significant \\
\hline $\mathrm{C}$ & -1.100 & -7.52 & $1 \%$ \\
\hline$D \operatorname{Ln}\left(R R_{t}\right)$ & 0.220 & -1.77 & insignificant \\
\hline$D \operatorname{Ln}\left(I N I_{t}\right)$ & 1.81 & 4.02 & $1 \%$ \\
\hline$D \operatorname{Ln}\left(F I D_{t}\right)$ & 0.202 & 10.99 & $1 \%$ \\
\hline$D \operatorname{Ln}\left(R E X_{t}\right)$ & -4.138 & -5.50 & $1 \%$ \\
\hline $\operatorname{DLn}\left(C R P_{t}\right)$ & -0.500 & -5.07 & $5 \%$ \\
\hline DUM $_{t}$ & -0.001 & -5.20 & $1 \%$ \\
\hline$S Q R T(G A R C H)$ & -0.302 & -1.62 & $1 \%$ \\
\hline \multicolumn{4}{|c|}{ Variance equation } \\
\hline $\mathrm{C}$ & 0.036 & 22.80 & $1 \%$ \\
\hline $\operatorname{RESID}(-1)^{2}$ & 0.361 & 3.17 & $8 \%$ \\
\hline \multirow[t]{2}{*}{ GARCH(-1) } & 1.05 & 2.577 & $1 \%$ \\
\hline & Durbin- Watson $=1.80$ & Adjusted R-squared $=0.761$ & R-squared $=0.829$ \\
\hline
\end{tabular}

Results of estimating the model, $D \operatorname{Ln}\left(S P I_{t}\right)$. 
According to Table 3 which shows the results of analyzing the study model ${ }^{3}$ depending on the data of the net portfolio investments during the period 1996-2018, it is shown that the fluctuations in the industrial production index and the net portfolio investments have a positive effect on the fluctuations in the stock price index. On the other hand, the fluctuations in the real effective exchange rate index and the average price of Brent crude have a negative effect on the fluctuations in the stock price index. There is also a negative effect of the years of instability and the standard deviation of the estimation remainders (which represents risk) on the fluctuations in the stock price index in Amman Stock Exchange. However, the fluctuations in the real interest rate did not have an acceptable statistical effect on the stock price fluctuations. This, perhaps, was due to the short period of time for the analysis, the many variables used as well as the need for a larger number of degrees of freedom.

To ensure the credibility of the results, the data were reanalyzed after replacing net portfolio investments with the financial account minus net foreign direct investment as its data were available during the entire study period 1980-2018. Thus, there were a larger number of degrees of freedom. Table 4 shows the results of analyzing the study model. It is clear how the results in Table 4 are similar to the results in Table 3 considering, at least, the direction of the effect. Moreover, the variable of the real interest rate became statistically significant. Accordingly, the results shown in table (4) haven been adopted in this study. They can be illustrated as follows:

Table 4

Results of estimating the model, $D \operatorname{Ln}\left(S P I_{t}\right)$

\begin{tabular}{|c|c|c|c|}
\hline \multicolumn{4}{|c|}{ Mean equation } \\
\hline Variable & coefficient & Z-statistics & Level of significant \\
\hline $\mathrm{C}$ & -0.177 & -7.52 & $1 \%$ \\
\hline$D \operatorname{Ln}\left(R R_{t}\right)$ & -0.038 & -1.77 & $10 \%$ \\
\hline$D \operatorname{Ln}\left(I N I_{t}\right)$ & 0.690 & 4.02 & $1 \%$ \\
\hline$D \operatorname{Ln}\left(F I D_{t}\right)$ & 1.228 & 10.99 & $1 \%$ \\
\hline$D \operatorname{Ln}\left(R E X_{t}\right)$ & -1.333 & -5.50 & $1 \%$ \\
\hline$D \operatorname{Ln}\left(C R P_{t}\right)$ & -0.246 & -5.07 & $5 \%$ \\
\hline $\mathrm{DUM}_{\mathrm{t}}$ & -0.086 & -5.20 & $1 \%$ \\
\hline$S Q R T(G A R C H)$ & -0.359 & -1.62 & $10 \%$ \\
\hline \multicolumn{4}{|c|}{ Variance equation } \\
\hline $\mathrm{C}$ & 0.018 & 22.80 & $1 \%$ \\
\hline $\operatorname{RESID}(-1)^{2}$ & 0.293 & 3.17 & $1 \%$ \\
\hline \multirow{2}{*}{ GARCH(-1) } & 0.340 & 2.577 & $1 \%$ \\
\hline & Durbin-Watson=2.042 & Adjusted R-squared $=0.476$ & R-squared $=0.575$ \\
\hline
\end{tabular}

First: There is a statistically significant positive effect at the significance level $1 \%$ of the industrial production quantity index on the fluctuations in the stock price index. The improvement in industrial production index refers to the increase in the level of real economic activity, which means the increase in GDP and thus increasing incomes, then increasing savings accompanied by increasing investments in the stock market, which lead to upward fluctuations in the stock price index.

Second: There is a statistically significant positive effect at the significance level $1 \%$ of the portfolio investments on the fluctuations in the stock price index. This indicates that the increase in the growth rate of net portfolio investments causes upward fluctuations in the stock price index. This illustrates that the increase in the foreign appetite for investing in the Jordanian stock market enhances its reputation and standing and motivates more investors to enter the financial market, which results in more demand for the stock and, thus, leads to the increase in its general price level.

Third: There is a statistically significant negative effect of the index of real effective exchange rate on the fluctuations in the stock price index as the increase in the index of real effective exchange rate is an indication of currency appreciation. Thus, it becomes costly, whether for local investors, especially when there are investment alternatives in the foreign markets rather than the local markets, or for foreign investors as the appreciation of the local currency makes foreign investors reluctant to invest in the local capital market. Therefore, both cases decrease the demand for the stock, which leads the stock index to go down in the local market.

Fourth: There is a statistically significant negative effect of the average price of Brent crude on the fluctuations in the stock price index as the price of Brent crude reflects the external fluctuations. Moreover, since the Jordanian economy is a small

\footnotetext{
3 -The fluctuations of the time series are those changes that occur in it over time which are often dependents on each other. For example, the change in the current stock price is related to the changes that occurred in the past. Thus, the time series is not studied in its level, but it is studied by its growth rates. Accordingly, the natural logarithm of the variables was taken (after adding a constant number to the series which contains minus values so that all its values become positive). Then, the change is taken to be in the form of $D \operatorname{Ln}\left(X_{t}\right)$. Thus, growth rates in variables are calculated, which is appropriate for the subject of the study that is concerned about fluctuations. In addition, variables become stable at the level in order to be suited to the analysis methodology used in the study.
} 
economy, open to external economies and dependent on imported energy, it is highly vulnerable to external factors. Furthermore, pessimistic projections would quickly move inward decreasing stock prices.

Fifth: There is a statistically significant negative effect at the significance level $10 \%$ of the real interest rate on the fluctuations in the stock price index. The increase in the real interest rate would have a negative impact on the investment decision. This is relevant in two cases. The first case is when the investor is willing to borrow for speculation in the stock market as the increase in the interest rate means more cost increase to the investor. This limits his investment decision in the stock market. The second case is when the investor is willing to invest private funds in the stock market. Moreover, when the real interest rate increases in banks, the investor will prefer it over taking risks in the stock market. Consequently, stock investments become fewer in the stock market, which would negatively affect the level of its prices.

Sixth: Results showed that the expected risk in the stock market, which was measured by the standard deviation of the remainders of estimation calculated according to GARCH model, has a negative effect on the fluctuations in the stock price index. The more expected risks in the stock market lead investors to be reluctant to invest in that market. Thus, the demand for the stock would decrease and, then, the level of its prices would decrease as well.

Seventh: There is a negative statistically significant impact of the years of instability that Jordan had passed, which was measured by the dummy variable on the stock price index. This confirms the association of the domestic financial market with external events that cast a shadow on its indicators.

\section{Conclusion}

There are many previous domestically and internationally studies that have dealt with the impact of fluctuations in economic variables on the fluctuations of stock prices, and the results of this study are somewhat consistent with previous studies conducted locally, such as AL-Rafai (1999), and Al- Hammouri (1999), but this study added indirect foreign investment and price of world crude oil to capture the impact of international economic variables on the local stock prices index, which shows that domestic stock prices are positively affected by foreign indirect investments and negatively affected by world oil prices. Therefore, these results recommended encouraging increased foreign capital flows to invest in the Jordanian stock market by encouraging foreign investors to create an appropriate investment environment that enjoys stable investment and tax laws, facilitate investment procedures, facilitate arbitration cases related to their investments and resolve their tendencies - if any, and diversify energy sources and try to find different alternatives to imported oil derivatives; Quantities of industrial production that positively affect the stock price index. When comparing the results of this study with the results of previous foreign studies, it was found that they were often consistent with them, particularly in terms of the interest rate and the gross domestic product or the industrial production index, which is often used to indicate the volume of real economic activity, how much was stated in the Nasseh (2000), Ratanapakorn and Sharma (2007) and Demir (2019). However, the difference between this study and previous studies is that this study did not use inflation and money supply as in other studies because when they were introduced into the model, the results found were non- statistically acceptable. This may be due to the existence of a multicollenarity between them, or with other variables such as the link between money supply and interest rate, or between inflation and the world oil price, especially since the Jordanian economy is dependent on import crude oil, and a part of domestic inflation is imported. Another possibility is that these variables may affect the stock prices index, in particular a sector without other. Therefore, these results may lead future studies to investigate the macroeconomic determinants that can affect the stock prices index in the Jordanian stock market at the sector level and not the general stock price index.

\section{References}

Anichebe, A. S.(2019). Macroeconomic determinants of Stock Price in Nigeria. European Journal of Business and Management, 11(21), 96-103.

Azeez, B. A., \& Obalade, A. A. (2018). Macroeconomic determinants of stock market development in Nigeria:(1981-2017). Acta Universitatis Danubius. Economica, 15(1).

Bekaert, G., Erb, C. B., Harvey, C. R., \& Viskanta, T. E. (1998). Distributional characteristics of emerging market returns and asset allocation. Journal of Portfolio Management, 24(2), 102.

Chen, N. F., Roll, R., \& Ross, S. A. (1986). Economic forces and the stock market. Journal of Business, 59(3), 383-403.

Chen, S. S. (2009). Predicting the bear stock market: Macroeconomic variables as leading indicators. Journal of Banking \& Finance, 33(2), 211-223.

Demir, C. (2019). Macroeconomic determinants of stock market fluctuations: The case of bist-100. Economies, 7(1), 8.

Fama, E. F. (1981). Stock returns, real activity, inflation, and money. The American Economic Review, 71(4), 545-565.

Fama, E. F., \& Schwert, G. W. (1977). Asset returns and inflation. Journal of Financial Economics, 5(2), 115-146. 
Geske, R., \& Roll, R. (1983). The fiscal and monetary linkage between stock returns and inflation. The Journal of Finance, $38(1), 1-33$.

Gujarati, D. N. (2009). Basic econometrics. Tata McGraw-Hill Education.

Al-Hammouri, N. (1999). The relationship between stock returns volatility and macroeconomic variables volatility, empirical study. unpublished Dissertation, University of Jordan, Amman - Jordan, 1999.

Hamao, Y. (1987). An empirical investigation of the arbitrage pricing theory. Management International Review, 27(1), 1322.

Huang, R. D., \& Kracaw, W. A. (1984). Stock market returns and real activity: a note. The Journal of Finance, 39(1), $267-273$.

Muradoglu, G., Taskin, F., \& Bigan, I. (2000). Causality between stock returns and macroeconomic variables in emerging markets. Russian \& East European Finance and Trade, 36(6), 33-53.

El-Nader, H. M., \& Alraimony, A. D. (2013). The macroeconomic determinants of stock market development in Jordan. International Journal of Economics and Finance, 5(6), 91-103.

Nisha, N. (2016). Macroeconomic determinants of the behavior of Dhaka Stock Exchange (DSE). International Journal of Asian Business and Information Management (IJABIM), 7(1), 1-17.

Phillips, P. C., \& Hansen, B. E. (1990). Statistical inference in instrumental variables regression with I (1) processes. The Review of Economic Studies, 57(1), 99-125.

AL-Rafai, M. (1999). The impact of economic variables on the stock prices and trading volume in Amman Financial Market (1978-1997). Unpublished thesis, AL- Aalbayt University, Almafraq - Jordan, 1999.

Ratanapakorn, O., \& Sharma, S. C. (2007). Dynamic analysis between the US stock returns and the macroeconomic variables. Applied Financial Economics, 17(5), 369-377.

Ross, S. (1976). The arbitrage theory of capital asset pricing. Journal of Economic Theory, 13(3), 341-360.

Şükrüoğlu, D., \& Nalin, H. T. (2014). The macroeconomic determinants of stock market development in selected European countries: Dynamic panel data analysis. International Journal of Economics and Finance, 6(3), 64-71.

Tachiwou, A. M. (2009). Causality tests between stock market development and economic growth in West African Monetary Union. Economia. Seria Management, 12(2), 14-27.

Nasseh, A., \& Strauss, J. (2000). Stock prices and domestic and international macroeconomic activity: a cointegration approach. The Quarterly Review of Economics and Finance, 40(2), 229-245.

Zhou, J., Zhao, H., Belinga, T., \& Gahe, Z. S. Y. (2015). Macroeconomic determinants of stock market development in Cameroon. International Journal of Scientific and Research Publications, 5(1), 1-11.

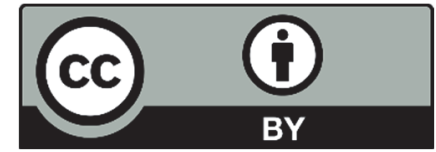

(C) 2021 by the authors; licensee Growing Science, Canada. This is an open access article distributed under the terms and conditions of the Creative Commons Attribution (CC-BY) license (http://creativecommons.org/licenses/by/4.0/). 